\title{
Co-occurrence of Cylindrospermopsis raciborskii (Woloszynska) Seenaya \& Subba Raju and Microcystis panniformis Komárek et al. in Mundaú reservoir, a semiarid Brazilian ecosystem
}

Coocorrência de Cylindrospermopsis raciborskii (Woloszynska) Seenaya \& Subba Raju e Microcystis panniformis Komárek et al. no reservatório Mundaú, um ecossistema do semiárido brasileiro

Ariadne do Nascimento Moura ${ }^{1}$, Maria do Carmo Bittencourt-Oliveira, ${ }^{1,2}$,

Mathias Alii Chia ${ }^{2}$ and Juliana Santos Severiano ${ }^{1}$

${ }^{1}$ Programa de Pós-graduação em Botânica, Universidade Federal Rural de Pernambuco - UFRPE,

Rua D. Manoel de Medeiros, s/n, Dois Irmãos, CEP 52171-030, Recife, PE, Brazil

e-mail: ariadne_moura@hotmail.com; mbitt@usp.br; jsantosseveriano@gmail.com

${ }^{2}$ Departamento de Ciências Biológicas, Escola Superior de Agricultura "Luiz de Queiroz" - ESALQ,

Universidade de São Paulo - USP, Av. Pádua Dias, 11, CEP 13418-900, Piracicaba, SP, Brazil

e-mail:machia@usp.br

\begin{abstract}
The influence of temperature and nutrients on the co-occurrence of Cylindrospermopsis raciborskii and Microcystis panniformis in Mundaú reservoir was investigated. Samples were collected bimonthly from September 2008 to March 2009 with a Van Dorn bottle at two depths (surface and bottom) $(\mathrm{n}=16)$. Water temperature was greater than $22.50^{\circ} \mathrm{C}$; $\mathrm{pH}$ values ranged from 6.09 to 8.42 ; and nitrogen-phosphorus ratios were low (0.11-1.46). The low $\mathrm{N}: \mathrm{P}$ ratios indicated high phosphorus input, and an eutrophic to hypereutrophic condition in the reservoir. A significant positive correlation of spatial and temporal distribution of $C$. raciborskii with $M$. panniformis was observed. Canonical correlation analysis (CCA) results revealed significant association of the biomass of most cyanobacterial species with temperature and nutrients concentration. However, these factors did not explain the co-occurrence of $C$. raciborskii and $M$. panniformis. On the other hand, morphological and physiological adaptations such as the possession of aerotopes and production of mucilage, and co-operation between the two species permitted niche overlap, and consequently the co-occurrence of C. raciborskii and M. panniformis in Mundaú reservoir.
\end{abstract}

Keywords: cyanobacteria; physicochemical conditions; co-occurrence; phytoplankton spatial distribution.

Resumo: Este estudo analisou a possível influência da temperatura e nutrientes (fósforo total ortofosfato, fósforo total dissolvido, nitrogênio total, nitrito e nitrato) na coocorrência de Cylindrospermopsis raciborskii e Microcystis panniformis no reservatório Mundaú, um ecossistema do semiárido do nordeste do Brasil. Amostras foram coletadas bimestralmente com uma garrafa de Van Dorn, de setembro 2008 a março 2009, em duas profundidades (superfície e fundo) em uma estação amostral, totalizando 16 amostras. A temperatura esteve sempre acima de $22.50^{\circ} \mathrm{C}$ e o pH variou entre ácido a alcalino (6.09-8.42). A relação nitrogênio-fósforo foi baixa (0.11-1.46), indicando um aumento da concentração de fósforo, contudo, o reservatório esteve de eutrófico a hipertrófico dependendo do período de amostragem. Mudanças na distribuição espacial e temporal das biomassas de C. raciborskii e M. panniformis foram similares para ambas as espécies, as quais foram confirmadas pela correlação positiva entre elas. A Análise de Correlação Canônica (ACC) mostrou uma forte correlação entre a biomassa da maioria das espécies de cianobactérias com as variáveis abióticas, principalmente temperatura e nutrientes. Apesar disto, estes fatores não explicaram a coocorrência de $C$. raciborskii e $M$. panniformis. Por outro lado, as adaptaçóes morfológicas e fisiológicas, tais como a posse de aerótopos e produção de mucilagem, e cooperação entre as duas espécies permitiram a sobreposição de nichos e, consequentemente, a co-ocorrência de C. raciborskii e $M$. panniformis no reservatório Mundaú.

Palavras-chave: cyanobacteria; condições físico-químicas; coocorrência; distribuição espacial do fitoplâncton. 


\section{Introduction}

The occurrence and excessive proliferation of cyanobacteria are closely associated with changing of global climatic conditions and eutrophication of aquatic resources. Despite the important role environmental variables play in cyanobacterial dominance, their success in a given aquatic ecosystem is directly dependent on their life strategies and ecological needs (Dokulil \& Teubner, 2000; Carey et al., 2012).

The worldwide distribution of Cylindrospermopsis and Microcystis spp., and their potential toxigenicity pose serious environmental challenges to water resource managers (Chia \& Kwaghe, 2015). Most studies have focused on cyanobacterial ecology and toxigenicity (Chia et al., 2009; Bonilla et al., 2012; Bittencourt-Oliveira et al., 2014; Borges et al., 2015), while the factors that control the co-occurrence of Cylindrospermopsis raciborskii and Microcystis panniformis are yet to be investigated. Recent studies have been aimed at understanding the morphological and physiological characteristics that enable Microcystis and Cylindrospermopsis species to co-dominate/ co-occur with other phytoplankton species (Moustaka-Gouni et al., 2009; Soares et al., 2009; Xie et al., 2011). The adaptations to different environmental conditions confer on cyanobacteria competitive advantage over other phytoplankton species (Piccin-Santos \& Bittencourt-Oliveira, 2012; Marinho et al., 2013). For example, intracellular nutrient storage ability and atmospheric nitrogen fixation with heterocysts (Dokulil \& Teubner, 2000; Briand et al., 2002); morphological adaptations to defend against excessive grazing (Bouvy et al., 2000; Albay \& Akçaalan, 2003; Reynolds, 2007), and the presence of aerotopes (gas vesicles), which permits buoyancy (Hasler \& Poulícková, 2003; Xiao et al., 2012) and access to photosynthetic active radiation (van Liere \& Walsby, 1982).

The norm in natural aquatic ecosystems is the alternation of $C$. raciborskii blooms with those of other cyanobacteria or microalgae. For example, the substitution or alternation of C. raciborskii dominance with species of Microcystis is closely related to seasonality (Marinho \& Huszar, 2002; Costa et al., 2006). However, Moura et al. (2011) showed that C. raciborskii was capable of forming multispecies blooms with non-heterocystous filamentous cyanobacteria in eutrophic/hypereutrophic tropical and subtropical reservoirs. Investigations into the co-occurrence of cyanobacterial species are still in their beginning stages. Marinho et al. (2013) is the only published work showing the competition for light and phosphorus by $M$. aeruginosa and C. raciborskii strains. However, this study was carried out in the laboratory under controlled conditions. Therefore, the objective of the present study was to determine the abiotics factors that determine the co-occurrence of $C$. raciborskii and $M$. panniformis in Mundaú reservoir, a semiarid Brazilian reservoir.

\section{Material and Methods}

Mundaú Reservoir ( $08^{\circ} 56^{\prime} 776^{\prime \prime} \mathrm{S}$ and $36^{\circ} 29^{\prime} 552^{\prime \prime} \mathrm{W}$ ) is located in the semiarid region of the state of Pernambuco, northeastern Brazil. The reservoir is situated at an altitude of $716 \mathrm{~m}$. It has maximum capacity of $1.9 \times 10^{6} \mathrm{~m}^{3}$ and maximum depth of $9 \mathrm{~m}$ (ANA, 2013). The reservoir receives large amount of sewage from domestic and industrial sources (ANA, 2013).

Pernambuco state is characterized by long drought periods and the duration of the present investigation was not an exception. During the present study, average precipitation ranged from 0 to $0.12 \mathrm{~mm}$ and temperature from 18.65 to $23.07^{\circ} \mathrm{C}$ (INMET, 2013).

Duplicate samples were collected in September 2008, November 2008, January 2009 and March 2009 at a sampling station located near the reservoir dam and at two different depths (subsurface, $0.2 \mathrm{~m}$; and bottom, $\times 3$ Secchi disk depth of extinction).

Samples for biological analysis were collected using a Van Dorn bottle, and preserved with Lugol's solution in $100 \mathrm{~mL}$ amber flasks. Taxonomic analysis was carried out using a Zeiss Jenaval microscope and published identification keys (Komárek \& Anagnostidis, 1989, 1998, 2005; Komárek et al., 2002).

Biomass quantification was performed using an inverted microscope (Zeiss, model Axiovert 135M), following the Utermöhl method (Utermöhl, 1958). At least 100 individuals of the most frequent species or 400 individuals were counted in random fields. Cell densities were converted into biovolume following the procedure described by Hillebrand et al. (1999) and biomass in mg. $\mathrm{L}^{-1}$ according to Wetzel \& Likens (2000). Abundance and dominance were determined using the method described by Lobo \& Leighton (1986). Abundant species were classified as those with cell densities above the community average density, while dominant species were those with cell densities above $50 \%$ of the community total density. 
Dissolved oxygen and water temperature were measured in situ with an Oximeter (HandyLab OX1/SET). Water turbidity measurement was done with a Turbidimeter (HANNA HI93703), while $\mathrm{pH}$ was determined with a potentiometer (DMPH-2). The concentrations of the following nutrients were analyzed: total phosphorus (Valderrama, 1981), orthophosphate and total dissolved phosphorus (Strickland \& Parsons, 1965), total nitrogen (Valderrama, 1981), and nitrite and nitrate (Mackereth et al., 1978). Nitrogen to phosphorus $(\mathrm{N}: \mathrm{P})$ ratios were calculated according to Downing \& McCayley (1992). The Carlson Trophic State Index (Carlson, 1977) was used for the trophic characterization of the water body.

Two-way analysis of variance was used to verify the existence of vertical and temporal differences in the environmental variables. The co-occurrence of $C$. raciborskii and $M$. panniformis was evaluated using Pearson's correlation coefficient $(r)$. After the confirmation of a positive correlation between the occurrences of the two species, correlation tests between their biomass and abiotic variables were performed to determine which abiotic factor was responsible for the growth of these taxa. In the event of a significant relationship $(p<0.05)$, a partial correlation test $\left(r_{\mathrm{XY} . \mathrm{Z}}\right)$ was conducted to investigate the influence of the variable on the co-occurrence of these cyanobacteria. The BioEstat v5.0 statistical program was used for these analyses (Ayres et al., 2003).

Canonical correlation analysis (CCA) was performed using the $\mathrm{R}$ software, to confirm significant interactions of environmental factors with the co-occurrence of $C$. raciborskii and $M$. panniformis. The biotic data matrix included species of cyanobacteria that contributed to more than $5 \%$ of the total biomass in at least one sampling unit per time. Abiotic variables were phased out using the routine forward selection available in the Canoco 4.5 software. The significance of the CCA was evaluated using the Monte Carlo test with 999 unrestricted permutations. All analyses were done at $5 \%$ significance level.

\section{Results}

The monthly and vertical variations of hydrological variables are shown in Table 1. Significant differences were observed between the depths for dissolved oxygen $(\mathrm{F}=18.88$, $p<0.01)$ and turbidity $(\mathrm{F}=18.096, p<0.01)$, and between months for $\mathrm{pH}(\mathrm{F}=13.19, p<0.05)$ and orthophosphate $(\mathrm{F}=8.77, p<0.05)$.

Table 1. Physicochemical conditions of Mundaú reservoir, Pernambuco, Brazil, during the present investigation. $\mathrm{S}=\operatorname{subsurface}(0.20 \mathrm{~cm}) ; \mathrm{B}=$ bottom $(2.5 \mathrm{~m})$.

\begin{tabular}{|c|c|c|c|c|c|}
\hline Variables & & $\begin{array}{c}\text { September } \\
2008\end{array}$ & $\begin{array}{c}\text { November } \\
2008 \\
\end{array}$ & $\begin{array}{c}\text { January } \\
2009\end{array}$ & $\begin{array}{c}\text { March } \\
2009 \\
\end{array}$ \\
\hline \multirow{2}{*}{ Water Temperature $\left({ }^{\circ} \mathrm{C}\right)$} & $S$ & 24.30 & 25.80 & 26.10 & 27.20 \\
\hline & $\mathrm{B}$ & 22.50 & 23.80 & 25.20 & 24.40 \\
\hline \multirow{2}{*}{ Dissolved Oxygen (mg. L-1) } & $S$ & 6.31 & 6.30 & 2.14 & 7.20 \\
\hline & $\mathrm{B}$ & 0.00 & 0.20 & 1.29 & 0.00 \\
\hline \multirow{2}{*}{ Turbidity (UNT) } & $\mathrm{S}$ & 109.00 & 82.00 & 98.06 & 172.00 \\
\hline & $\mathrm{B}$ & 25.92 & 27.77 & 42.72 & 18.28 \\
\hline \multirow{2}{*}{$\mathrm{pH}$} & $S$ & 8.16 & 7.00 & 7.86 & 8.46 \\
\hline & $\mathrm{B}$ & 8.08 & 6.09 & 7.82 & 8.42 \\
\hline \multirow{2}{*}{ Total phosphorus ( $\mu \mathrm{g} . \mathrm{L}-1)$} & $\mathrm{S}$ & 293.28 & 286.23 & 431.47 & 552.75 \\
\hline & $\mathrm{B}$ & 445.57 & 317.25 & 445.57 & 962.55 \\
\hline \multirow{2}{*}{ Total dissolved phosphorus ( $\mu \mathrm{g} . \mathrm{L}-1)$} & $\mathrm{S}$ & 247.31 & 137.74 & 102.25 & 371.33 \\
\hline & $\mathrm{B}$ & 300.52 & 115.83 & 120.68 & 445.95 \\
\hline \multirow{2}{*}{ Orthophosphate ( $\mu \mathrm{g} . \mathrm{L}-1)$} & $S$ & 55.99 & 55.99 & 94.55 & 64.11 \\
\hline & $\mathrm{B}$ & 125.66 & 33.59 & 85.34 & 215.24 \\
\hline \multirow{2}{*}{ Total nitrogen $(\mu \mathrm{g} . \mathrm{L}-1)$} & $\mathrm{S}$ & 132.14 & 162.64 & 62.75 & 41.83 \\
\hline & $\mathrm{B}$ & 635.30 & 452.33 & 65.74 & 53.78 \\
\hline \multirow{2}{*}{ Nitrite ( $\mu \mathrm{g} . \mathrm{L}-1)$} & $S$ & 30.01 & 13.34 & 1.06 & 2.11 \\
\hline & $\mathrm{B}$ & 456.81 & 11.11 & 2.11 & 4.23 \\
\hline \multirow{2}{*}{ Nitrate $(\mu \mathrm{g} . \mathrm{L}-1)$} & $\mathrm{S}$ & 136.31 & 54.52 & 14.79 & 5.69 \\
\hline & $\mathrm{B}$ & 156.81 & 87.24 & 4.55 & 2.27 \\
\hline \multirow{2}{*}{ TN:TP } & $S$ & 0.45 & 0.57 & 0.15 & 0.11 \\
\hline & $\mathrm{B}$ & 1.42 & 1.46 & 0.15 & 0.12 \\
\hline
\end{tabular}


The highest biomass was recorded in the subsurface, where $M$. panniformis was dominant. Cyanobacterial species such as $C$. raciborskii, Geitlerinema amphibium (Agardh ex Gomont) Anagnostidis and Merismopedia punctata Meyen were abundant on at least one sampling date (Table 2). The highest biomass of $M$. panniformis and $C$. raciborskii was recorded in the subsurface, except in January 2009, when the highest biomass of $M$. panniformis was recorded at the bottom (Figure 1 and Table 2).

The biomass of $C$. raciborskii was positively correlated $(\mathrm{r}=0.98)$ with that of $M$. panniformis.

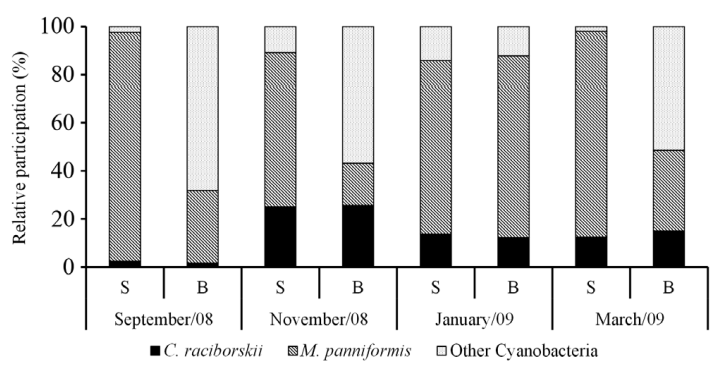

Figure 1. Biomass variation of total cyanobacterial population, C. raciborskii, $M$. panniformis and other cyanobacteria without $C$. raciborskii and $M$. panniformis in the subsurface $(S)$ and at the bottom (B) of the water column of Mundaú reservoir, Pernambuco, Brazil.
Furthermore, the change in the biomass of both cyanobacteria was positively correlated with temperature $\left(r_{\text {C.raciborskii }}=0.80\right.$ and $\left.r_{\text {M.panniformis }}=0.75\right)$ and turbidity $\left(r_{\text {C.raciborkii }}=0.79\right.$ and $\left.r_{\text {M.panniformis }}=0.82\right)$. However, the correlation between these cyanobacteria remained significant even when the abiotic conditions were constant $\left(r_{\text {XY.temperature }}=0.96 ; r_{\text {XY.turbidity }}=0.94 ; p<0.01\right)$.

Canonical correlation analysis results showed that the first two axes were responsible for $80.3 \%$ of the total variation. In addition, within the first two CCA axes, environmental variables explained $91.4 \%$ of total biological data variation. There was a significant correlation between cyanobacterial biomass and physicochemical conditions of the reservoir (Figure 2 and Table 3 ).

The side by side ordination of $C$. raciborskii and $M$. panniformis near the origin of the axes confirmed their co-occurrence. Although the CCA demonstrated that temperature and nutrients were determinant factors of cyanobacterial growth, these variables could not explain the co-occurrence of $C$. raciborskii and $M$. panniformis. Vertical differences in the biological and environmental data were related to the first axis of the CCA. G. amphibium and Me. punctata were positively associated with total nitrogen, but negatively related to temperature (Table 3 and Figure 2). On the

Table 2. Changes in cyanobacterial biomass (mg. $\left.\mathrm{L}^{-1}\right)$ in Mundaú Reservoir, Pernambuco, Brazil, during the study.

\begin{tabular}{|c|c|c|c|c|c|c|c|c|}
\hline \multirow{2}{*}{ Species } & \multicolumn{2}{|c|}{$\begin{array}{l}\text { September } \\
2008\end{array}$} & \multicolumn{2}{|c|}{$\begin{array}{l}\text { November } \\
2008\end{array}$} & \multicolumn{2}{|c|}{$\begin{array}{l}\text { January } \\
2009\end{array}$} & \multicolumn{2}{|c|}{$\begin{array}{l}\text { March } \\
2009\end{array}$} \\
\hline & $\mathbf{S}$ & B & $\mathbf{S}$ & B & $\mathbf{S}$ & B & $\mathbf{S}$ & B \\
\hline $\begin{array}{l}\text { Aphanocapsa incerta (Lemmermann) } \\
\text { G.Cronberg \& Komárek }\end{array}$ & 0.002 & 0.001 & 0.0038 & 0 & 0.08 & 0.06 & 0 & 0.011 \\
\hline $\begin{array}{l}\text { Aphanocapsa elachista } \\
\text { West \& G.S.West }\end{array}$ & 0 & 0 & 0 & 0 & & 0.01 & 0 & 0.001 \\
\hline $\begin{array}{l}\text { Chroococcus limneticus } \\
\text { Lemmermann }\end{array}$ & 0 & 0 & 0 & 0 & 0.01 & 0 & 0 & 0.001 \\
\hline Chroococcus minor (Kützing) Nägeli & 0 & 0 & 0.0013 & 0.001 & 0 & 0 & 0 & \\
\hline $\begin{array}{l}\text { Chroococcus minutus (Keissl.) } \\
\text { Lemmermann }\end{array}$ & 0.01 & 0.001 & 0.0093 & 0.007 & 0.03 & 0.04 & 0 & 0.003 \\
\hline $\begin{array}{l}\text { Cylindrospermopsis raciborskii } \\
\text { (Woloszynska) Seenaya \& Subba } \\
\text { Raju }\end{array}$ & 0.20 & 0.022 & $2.97^{\circ}$ & $1.474^{\circ}$ & $3.12^{\circ}$ & $2.70^{\circ}$ & 12.69 & $0.458^{\circ}$ \\
\hline $\begin{array}{l}\text { Geitlerinema amphibium } \\
\text { (Agardh ex Gomont) Anagnostidis }\end{array}$ & 0.17 & $0.443^{\circ}$ & 0.39 & 0.916 & 1.61 & 1.03 & 1.87 & $0.642^{\circ}$ \\
\hline $\begin{array}{l}\text { Merismopedia glauca (Ehrenberg) } \\
\text { Kützing }\end{array}$ & 0 & 0 & 0 & 0 & 0 & 0 & 0 & 0.067 \\
\hline Merismopedia punctata Meyen & 0 & $0.357^{\circ}$ & 0.88 & $2.341^{\circ}$ & 1.22 & 1.36 & 0 & $0.692^{\circ}$ \\
\hline $\begin{array}{l}\text { Merismopedia tenuissima } \\
\text { Lemmermann }\end{array}$ & 0.004 & 0.107 & 0.0077 & 0.004 & 0.23 & 0.14 & 0.14 & 0.141 \\
\hline $\begin{array}{l}\text { Microcystis panniformis } \\
\text { Komárek et al. }\end{array}$ & $7.69^{*}$ & 0.402 & $7.61^{*}$ & $1.010^{\circ}$ & $16.42^{*}$ & $16.55^{*}$ & $86.68^{*}$ & $1.019^{\circ}$ \\
\hline Pseudanabaena catenata Lauterborn & 0 & 0 & 0 & 0 & 0.01 & 0.03 & 0 & 0.006 \\
\hline
\end{tabular}

Legends: $\mathrm{S}=$ subsurface; $\mathrm{B}=$ bottom. ${ }^{*}$ Dominant species. ${ }^{\circ}$ Abundant species. 
Table 3. Canonical correlation analysis (CCA) statistical summary results for cyanobacterial species and abiotic variables in Mundaú Reservoir, Pernambuco, Brazil.

\begin{tabular}{|c|c|c|c|c|}
\hline & & & Axis 1 & Axis 2 \\
\hline \multicolumn{3}{|l|}{ Eigenvalues } & 0.427 & 0.098 \\
\hline \multicolumn{3}{|c|}{ Accumulated variance in biotic data (\%) } & 65.3 & 80.3 \\
\hline \multicolumn{3}{|c|}{ Accumulated variance in species-environment relation (\%) } & 74.3 & 91.4 \\
\hline \multicolumn{3}{|l|}{ Species-environment correlation } & 0.998 & 0.921 \\
\hline \multicolumn{5}{|l|}{ Monte Carlo test } \\
\hline \multicolumn{3}{|c|}{ Significance of first canonical axis $-p$} & 0.001 & - \\
\hline \multicolumn{3}{|c|}{ Significance of all canonical axes $-p$} & 0.013 & - \\
\hline & \multicolumn{2}{|c|}{ Canonical coefficient } & \multicolumn{2}{|c|}{ Intra-set correlation } \\
\hline & Axis 1 & Axis 2 & Axis 1 & Axis 2 \\
\hline Nitrate $\left(\mathrm{NO}_{3}\right)$ & 0.95 & -0.27 & 0.95 & -0.29 \\
\hline Total dissolved phosphorus (TDP) & -0.05 & -0.80 & -0.05 & -0.87 \\
\hline Total nitrogen (TN) & 0.98 & 0.06 & 0.98 & 0.07 \\
\hline Water temperature $\left(\mathrm{T}^{\circ} \mathrm{C}\right)$ & -0.86 & 0.14 & -0.86 & 0.15 \\
\hline
\end{tabular}

$(-)$ : no correlation.
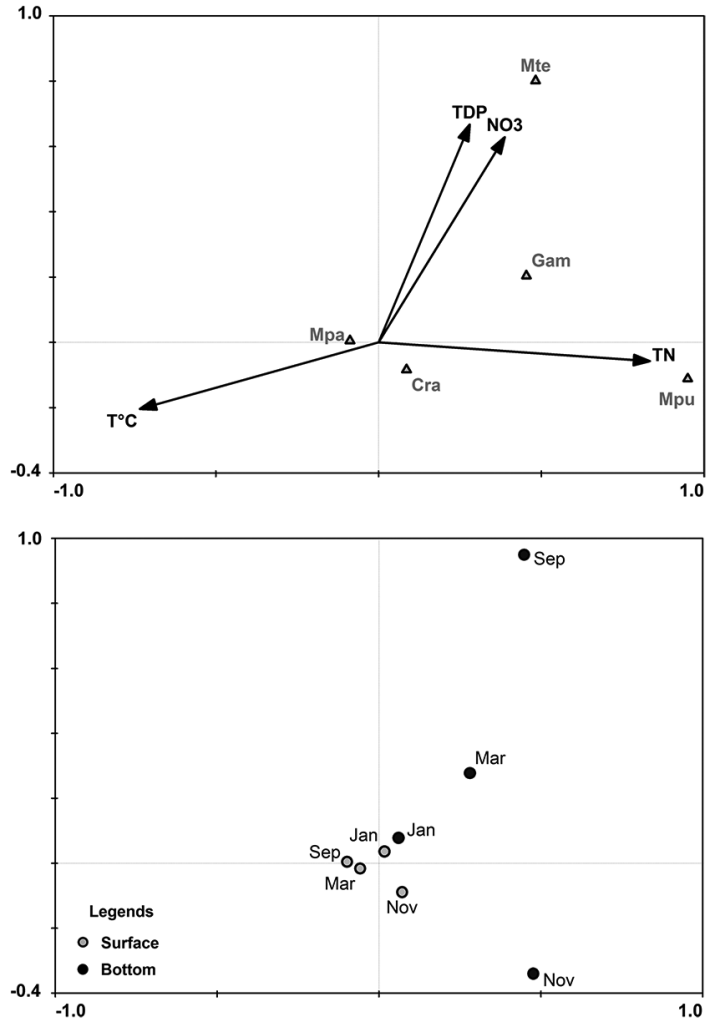

Figure 2. Canonical correlation analysis (CCA) biplot showing the relationship between the abundant phytoplankton species and abiotic conditions of Mundaú reservoir, Pernambuco, Brazil. Note: Jan = January, Mar = March, Sep = September, and Nov = November; the symbols represent water column depths, i.e. subsurface and bottom. NO3 = nitrate; $\mathrm{TDP}=$ total dissolved phosphorus; $\mathrm{TN}=$ total nitrogen; $\mathrm{T}^{\circ} \mathrm{C}=$ water temperature; $\mathrm{Cra}=$ Cylindrospermopsis raciborski; Gam = Geitlerinema amphibium; $\mathrm{Mpa}=$ Microcystis panniformis; $\mathrm{Mpu}=$ Merismopedia punctata and Mte = Merismopedia tenuissima. second axis, Merismopedia glauca (Ehrenberg) Kützing and Merismopedia tenuissima Lemmermann were positively related to total dissolved phosphorus and nitrate nitrogen (Table 3 and Figure 2).

\section{Discussion}

The growth of cyanobacteria, particularly their ability to form blooms, has been reported to be influenced by temperature, light quality and nutrient concentrations (Dokulil \& Teubner, 2000; Briand et al., 2002; Wiedner et al., 2002; Borges et al., 2008). This is in agreement with the results of the present study, as changes in the biomass of most cyanobacterial species were positively related to the nutrient content of Mundaú reservoir. In addition, the results of the present study revealed that $C$. raciborskii and $M$. panniformis co-occur in Mundaú reservoir. This is contrary to findings that the biomass of Microcystis alternates with that of $C$. raciborskii in several aquatic ecosystems (Marinho \& Huszar, 2002; Crossetti $\&$ Bicudo, 2008). Most studies report that C. raciborskii co-dominates/co-occurs with Lyngbya, Planktolyngbya and Planktothrix; while Microcystis co-dominates/co-occurs with other species of the same genus and Sphaerocavum (Kokocinski \& Soininen, 2012; Bonilla et al., 2012).

Although vertical temperature profile analyses were not performed to determine the presence or absence of thermal stratification, the difference between surface and bottom temperature was up to $2.8{ }^{\circ} \mathrm{C}$. This temperature variation between the surface and bottom is sufficient to infer the formation of strata in tropical lentic systems 
(Soares et al., 2013). In the present investigation, a significant correlation between temperature and the biomass of $C$. raciborskii and $M$. panniformis was observed. However, the co-occurrence of both species was not determined by temperature, as shown by the CCA result. This implied that other factors were responsible for the co-occurrence of both cyanobacterial species.

Ecophysiological and morphological adaptations of Cylindrospermopsis and Microcystis facilitate their success in Brazilian aquatic ecosystems. This is supported by field data (1999-2011), which show that Cylindropermopsis and Microcystis are well adapted to varying nutrient and physical conditions (Soares et al., 2013). Therefore, when environmental conditions are equilibrated or within certain levels, both species/strains may co-exist. The ability to adjust their position in the water column is a life strategy that supports the co-occurrence of M. panniformis and C. raciborskii (Reynolds, 2007). In addition, the potential to form intense surface blooms by Microcystis spp. is aided by the production of mucilage, which enhances their buoyancy and access to photosynthetic active radiation. This explains the dominance of $M$. panniformis in the subsurface and not the bottom of the water column. On the other hand, C. raciborskii is an opportunistic species, which absorbs and stores nutrients (Dokulil \& Teubner, 2000), fixes nitrogen using heterocysts (Briand et al., 2002), and is well adapted to stratified (Berger et al., 2006) and mixed waters (Burford et al., 2006). These characteristics explain its abundance in both the sub-surface and bottom regions of the water column.

Although photosynthetic active radiation is not a limiting factor in tropical regions of Brazil, the dominance and high biomass of $M$. panniformis can reduce light penetration. However, the dominance of $M$. panniformis, did not deter $C$. raciborskii from being abundant, as the latter was adapted to shade or low light condition caused by the high biomass of the former. Consequently, some form of "co-operation" between the two species was established, resulting in common life strategies and overlapped niche. Thus, the co-operation between the two species, as also supported by the significant positive correlation of their biomass, may be the defining factor for their co-occurrence in Mundaú reservoir.

Conclusions can be made that the temperature, turbidity and nutrient content determined the general dynamics of cyanobacteria in the Mundaú reservoir. However, the co-occurrence of
C. raciborskii and $M$. panniformis was independent of the physicochemical conditions. Primarily, the co-occurrence of both species was dependent on their life strategies. C. raciborskii and $M$. panniformis have morphological and physiological adaptations that take advantage of physicochemical changes in the water column. For example, the presence of aerotopes and mucilage aid maximum light capture and utilization. Also the probably co-operation between the two species permitted niche overlap, which allow the co-occurrence of both cyanobacterial species.

\section{Acknowledgements}

We are grateful to the "Conselho Nacional de Desenvolvimento Científico e Tecnológico (CNPq)" for financial support (Proc. 301715/2008-4, $302068 / 2011-2$ and $471603 / 2012-0)$ to carry out this study.

\section{References}

AGÊNCIA NACIONAL DAS ÁGUAS - ANA. Boletim de Acompanhamento dos Reservatórios do Nordeste [online], 2013, 8(10), 1-16 [viewed 24 June 2014]. Available from: http://arquivos. ana.gov.br/saladesituacao/BoletinsMensais/ ReservatorioNordeste/Boletim_Monitoramento_ Reser_Nordeste_2013_0107.pdf

ALBAY, M. and AKÇAALAN, R. Factors influencing the phytoplankton steady state assemblages in a drinking water reservoir (Ömerli reservoir, Istanbul). Hydrobiologia, 2003, 502(1-3), 85-95. http://dx.doi. org/10.1023/B:HYDR.0000004272.38702.c3.

AYRES, M., AYRES JUNIOR, M., AYRES, D.L. and SANTOS, AA. Software BioEstat, aplicações estatísticas nas áreas das ciências biomédicas. Versão 3.0. Belém: Sociedade Civil Mamirauá/MCT/CNPq, 2003.

BERGER, C., BA, N., GUGGER, M., BOUVY, M., RUSCONI, F., COUTÉ, A., TROUSSELLIER, $M$. and BERNARD, C.. Seasonal dynamics and toxicity of Cylindrospermopsis raciborskii in Lake Guiers (Senegal, West Africa). FEMS Microbiology Ecology, 2006, 57(3), 355-366. http://dx.doi.org/10.1111/ j.1574-6941.2006.00141.x. PMid:16907750.

BITTENCOURT-OLIVEIRA, M.C., PICCINSANTOS, V., MOURA, A.N., ARAGÁOTAVARES, N.K.C. and CORDEIROARAÚJO, M.K. Cyanobacteria, microcystins and cylindrospermopsin in public drinking supply reservoirs of Brazil. Anais da Academia Brasileira de Ciências, 2014, 86(1), 297-310. http://dx.doi.org/10.1590/0001-3765201302512. PMid:24676169.

BONILLA, S., AUBRIOT, L., SOARES, M.C.S., GONZÁLEZ-PIANA, M., FABRE, A., HUSZAR, 
V.L.M., LÜRLING, M., ANTONIADES, D., PADISÁK, J. and KRUK, C. What drives the distribution of the bloom forming cyanobacteria Planktothrix agardhii and Cylindrospermopsis raciborskii? FEMS Microbiology Letters, 2012, 79(3), 594-607. http://dx.doi.org/10.1111/j.15746941.2011.01242.x. PMid:22092489.

BORGES, H.L.F., BRANCO, L.H.Z., MARTINS, M.D., LIMA, C.S., BARBOSA, P.T., LIRA, G.A.S.T., BITTENCOURT-OLIVEIRA, M.C. and MOLICA, R.J.R. Cyanotoxin production and phylogeny of benthic cyanobacterial strains isolated from the northeast of Brazil. Harmful Algae, 2015, 43, 46-57. http://dx.doi.org/10.1016/j.hal.2015.01.003.

BORGES, P.A.F., TRAIN, S. and RODRIGUES, L.C. Spatial and temporal variation of phytoplankton in two subtropical Brazilian reservoirs. Hydrobiologia, 2008, 607(1), 63-74. http://dx.doi.org/10.1007/ s10750-008-9367-3.

BOUVY, M., FALCÃO, D., MARINHO, M., PAGANO, M. and MOURA, A. Occurrence of Cylindrospermopsis (Cyanobacteria) in 39 Brazilian tropical reservoirs during the 1998 drought. Aquatic Microbial Ecology, 2000, 23(1), 13-27. http://dx.doi. org/10.3354/ame023013.

BRIAND, J.F., ROBILLOT, C., QUIBLIERLLOBÉRAS, C., HUMBERT, J.F., COUTÉ, A. and BERNARD, C. Environmental context of Cylindrospermopsis raciborskii (Cyanobacteria) blooms in a shallow pond in France. Water Research, 2002, 36(13), 3183-3192. http://dx.doi.org/10.1016/ S0043-1354(02)00016-7. PMid:12188114.

BURFORD, M.A., MCNEALE, K.L. and MCKENZIESMITH, F.J. The role of nitrogen in promoting the toxic cyanophyte Cylindrospermopsis raciborskii in a subtropical water reservoir. Freshwater Biology, 2006, 51(11), 2143-2153. http://dx.doi.org/10.1111/ j.1365-2427.2006.01630.x.

CAREY, C.C., IBELINGS, B.W., HOFFMANN, E.P., HAMILTON, D.P. and BROOKES, J.D. Eco-physiological adaptations that favour freshwater cyanobacteria in a changing climate. Water Research, 2012, 46(5), 1394-1407. http://dx.doi.org/10.1016/j. watres.2011.12.016. PMid:22217430.

CARLSON, R.E. A trophic state index for lakes. Limnology and Oceanography, 1977, 22(2), 361-369. http://dx.doi.org/10.4319/lo.1977.22.2.0361.

CHIA, A.M., ABOLUDE, D.S., LADAN, Z., AKANBI, O. and KALABOMS, A. The presence of microcystins in aquatic ecosystems in Northern Nigeria: Zaria as a case study. Research Journal of Environmental Toxicology, 2009, 3(4), 170-178. http://dx.doi.org/10.3923/rjet.2009.170.178.

CHIA, M.A. and KWAGHE, M.J. Microcystins contamination of surface water supply sources in Zaria-Nigeria. Environmental Monitoring and
Assessment, 2015, 187(10), 606. http://dx.doi. org/10.1007/s10661-015-4829-3. PMid:26329267.

COSTA, I.A.S., AZEVEDO, S.M., SENNA, P.A., BERNARDO, R.R., COSTA, S.M. and CHELLAPPA, N.T. Occurrence of toxin-producing cyanobacteria blooms in a Brazilian semiarid reservoir. Brazilian Journal of Biology = Revista Brasileira de Biologia, 2006, 66(1B), 211-219. http:// dx.doi.org/10.1590/S1519-69842006000200005. PMid: 16710515.

CROssetTI, L.O. and BICUDO, C.E.M. Phytoplankton as a monitoring tool in a tropical urban shallow reservoir (Garças Pond): the assemblage index application. Hydrobiologia, 2008, 610(1), 161173. http://dx.doi.org/10.1007/s10750-008-9431-z.

DOKULIL, M.T. and TEUBNER. Cyanobacterial dominance in lakes. Hydrobiologia, 2000, 438(1-3), 1-12. http://dx.doi.org/10.1023/A:1004155810302.

DOWNING, J.A. and MCCAYLEY, E. The nitrogen: phosphorus relationship in lakes. Limnology and Oceanography, 1992, 37(5), 936-945. http://dx.doi. org/10.4319/lo.1992.37.5.0936.

HASLER, P. and POUlíCKOVÁ, A. Diurnal changes in vertical distribution and morphology of a natural population of Planktothrix agardhii (Gom.) Anagnostidis et Komárek (Cyanobacteria). Hydrobiologia, 2003, 506509(1-3), 195-201. http://dx.doi.org/10.1023/ B:HYDR.0000008566.17473.88.

HILLEBRAND, H., DÜRSELEN, C., KIRSCHTEL, D., POLLINGHER, U. and ZOHARY, T. Biovolume calculation for pelagic and benthic microalgae. Journal of Phycology, 1999, 5(2), 403-424. http:// dx.doi.org/10.1046/j.1529-8817.1999.3520403.x.

INSTITUTO NACIONAL DE METEREOLOGIA - INMET. Estaçōes convencionais [online]. Brasília, 2013 [viewed 25 Nov 2013]. Available from: http:// www.inmet.gov.br/portal/index.php?r=estacoes/ estacoesConvencionais

KOKOCIŃSKI, M. and SOININEN, J. Environmental factors related to the occurrence of Cylindrospermopsis raciborskii (Nostocales, Cyanophyta) at the northeastern limit of its geographical range. European Journal of Phycology, 2012, 47(1), 12-21. http:// dx.doi.org/10.1080/09670262.2011.645216.

KOMÁREK, J. and ANAGNOSTIDIS, K. Cyanoprokaryota. 1. Teil: Chroococcales. In H. ETTL, G. GÄRTNER, H. HEYNIG and D. MOLLENHAUER. Süsswasserflora von Mitteleuropa 19/1. Jena: Gustav Fischer, 1998, 548 p.

KOMÁREK, J. and ANAGNOSTIDIS, K. Modern approach to the classification system of cyanophytes 4 - Nostocales. Algological Studies/Archiv für Hydrobiologie, 1989, (56), 247-345.

KOMÁREK, J. and ANAGNOSTIDIS, K. Cyanoprokaryota. 2. Teil: Oscillatoriales. In B. 
BÜNDEL, L. KRIENITZ, G. GÄRTNER and M. SCHAGERL. Süsswasserflora von Mitteleuropa. München: Elsevier, 2005, 759 p.

KOMÁREK, J., KOMÁRKOVÁ-LEGNEROVÁ, J., SANT'ANNA, C.L., AZEVEDO, M.T.P. and SENNA, P.A.C. Two common Microcystis species (Chroococcales, Cyanobacteria) from tropical America, including M. panniformis sp. nov. Cryptogamie. Algologie, 2002, 23(2), 159-177.

LOBO, E. and LEIGHTON, G. Estructuras comunitarias de las fitocenosis planctónicas de los sistemas de desembocaduras de rios y esteros de la zona central de Chile. Revista de Biología Marina y Oceanografia, 1986, 22(1), 1-29.

MACKERETH, F.J.H., HERON, J. and TALLING, J.F. Water analysis: some revised methods for limnologists. Kendall: Titus Wilson e Son, 1978. 120 p. Freshwater Biological Association Scientific Publication, no. 36.

MARINHO, M.M. and HUSZAR, V.L.M. Nutrient availability and physical conditions as controlling factors of phytoplankton composition and biomass in a tropical reservoir (Southeastern Brazil). Archiv für Hydrobiologie, 2002, 153(3), 443-468.

MARINHO, M.M., SOUZA, M.B. and LÜRLING, M. Light and phosphate completion between Cylindrospermopsis raciborskii and Microcystis aeruginosa is strain depend. Microbial Ecology, 2013, 66(3), 479-488. http://dx.doi.org/10.1007/s00248013-0232-1. PMid:23636583.

MOURA, A.N., DANTAS, E.W., OLIVEIRA, H.S. and BITTENCOURT-OLIVEIRA, M.C. Vertical and temporal dynamics of cyanobacteria in the Carpina potable water reservoir in Northeastern Brazil. Brazilian Journal of Biology $=$ Revista Brasileira de Biologia, 2011, 71(2), 451-459. http:// dx.doi.org/10.1590/S1519-69842011000300015. PMid:21755163.

MOUSTAKA-GOUNI, M., KORMAS, K.A., VARDAKA, E., KATSIAPI, M. and GKELIS, S. Raphidiopsis mediterranea Skuja represents nonheterocytous life-cycle stages of Cylindrospermopsis raciborskii (Woloszynska) Seenayya et Subba Raju in Lake Kastoria (Greece), its type locality: Evidence by morphological and phylogenetic analysis. Harmful Algae, 2009, 8(6), 864-872. http://dx.doi. org/10.1016/j.hal.2009.04.003.

PICCIN-SANTOS, V. and BITTENCOURTOLIVEIRA, M.C. Toxic cyanobacteria in four Brazilian water supply reservoirs. Journal of Environmental Protection, 2012, 3(1), 68-73. http:// dx.doi.org/10.4236/jep.2012.31009.

REYNOLDS, C.S. Variability in the provision and function of mucilage in phytoplankton: facultative responses to the environment. Hydrobiologia, 2007, 578(1), 37-45. http://dx.doi.org/10.1007/s10750006-0431-6.
SOARES, M.C.S., DE A ROCHA, M.I., MARINHO, M.M., AZEVEDO, S.M.F.O., BRANCO, C.W.C. and HUSZAR, V.L.M. Changes in species composition during annual cyanobacterial dominance in a tropical reservoir: physical factors, nutrients and grazing effects. Aquatic Microbial Ecology, 2009, 57, 137-144. http://dx.doi.org/10.3354/ame01336.

SOARES, M.C.S., HUSZAR, V.L.M., MIRANDA, M.N., MELLO, M.M., ROLAND, F. and LÜRLING, M.. Cyanobacterial dominance in Brazil: distribution and environmental preferences. Hydrobiologia, 2013, 717(1), 1-12. http://dx.doi. org/10.1007/s10750-013-1562-1.

STRICKLAND, J.D.H. and PARSONS, T.R. $A$ manual of sea water analysis: with special reference to the more common micronutrients and to particulate organic material. Ottawa: Fisheries Research Board of Canada, 1965, 185 p. Bulletin Fisheries Research Board, vol. 125.

UTERMÖHL, H. Zur vervollkommnung der quantitativen phytoplankton-methodik. Mitteilungen der Internationalen Vereinigung für Theoretische Und Angewandte Limnologie, 1958, 9, 1-38.

VALDERRAMA, J.C. The simultaneous analysis of total nitrogen and total phosphorus in natural waters. Marine Chemistry, 1981, 10(2), 109-122. http:// dx.doi.org/10.1016/0304-4203(81)90027-X.

VAN LIERE, L. and WALSBY, A.E. Interactions of cyanobacteria with light. In N.G. CARR and B.A. WHITTON. The biology of cyanobacteria. Oxford: Blackwell, 1982, pp. 9-45.

WETZEL, R.G. and LIKENS, G.E. Limnological analyses. 3rd ed. New York: Springer-Verlag, 2000, $429 \mathrm{p}$.

WIEDNER, C., NIXDORF, B., HEINZE, R., WIRSING, B., NEUMANN, U. and WECKESSER, $\mathrm{J}$. Regulation of cyanobacteria and microcystin dynamics in polymictic shallow lakes. Archiv für Hydrobiologie, 2002, 155, 383-400.

XIAO, Y., GAN, N., LIU, J., ZHENG, L. and SONG, L. Heterogeneity of buoyancy in response to light between two buoyant types of cyanobacterium Microcystis. Hydrobiologia, 2012, 679(1), 297-311. http://dx.doi.org/10.1007/s10750-011-0894-y.

XIE, L., HAGAR, J., REDISKE, R.R., O'KEEFE, J., DYBLE, J., HONG, Y. and STEINMAN, A. The influence of environmental conditions and hydrologic connectivity on cyanobacteria assemblages in two drowned river mouth lakes. Journal of Great Lakes Research, 2011, 37(3), 470-479. http://dx.doi. org/10.1016/j.jglr.2011.05.002.

Received: 24 June 2014 Accepted: 16 November 2015 